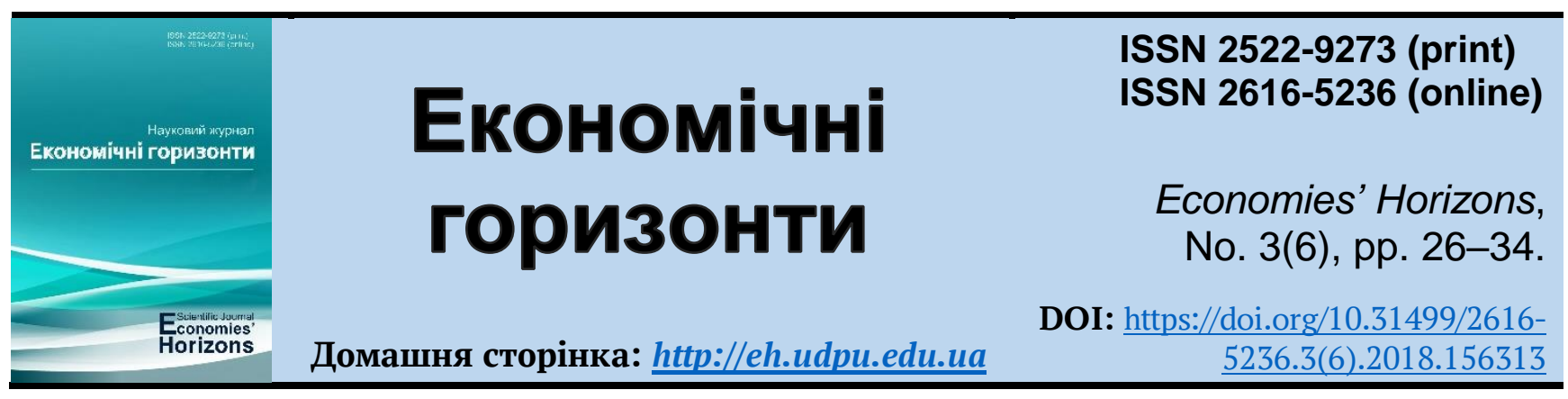

JEL Classification: J 24, M 12, M 21

\title{
Personnel competitiveness and its impact on sales of the company
}

\author{
Inna V. Korol ${ }^{1}$, Cand. Ec. Sc., Associate Professor
}

Olena V. Garmatiuk ${ }^{2}$

Received: 12 September 2018 Accepted: 26 September 2018
Korol, I. V. and Garmatiuk, O. V. (2018), "Personnel competitiveness and its impact on sales of the company", Economies' Horizons, No.3(6), pp. 26-34, doi: https://doi.org/10.31499/2616-5236.3(6).2018.156313.

Abstract. The purpose of the research. The aim of the paper is to generalize theoretical and methodological principles as well as develop recommendations aimed at improving personnel competitiveness management as a direction for improving the level of sales of the company. Methodology. The methodology for this study was based on methods of scientific abstraction, methods of the system-functional approach, grouping, generalization and formalization, analysis and synthesis. Results. The present article deals with the influence of personnel factors on sales performance of the company. The article observes the employee competitiveness. It proves that the employee competitiveness is not only one of the key factors influencing the growth of goods sales and serves, but also enterprise competitiveness as well. Basic theoretical foundations of employee competitiveness were investigated. It determines that the employee competitiveness is a combination of knowledge, abilities, skills and personal traits that enable employees to fulfill their responsibilities in the company. The article proposes a model incorporating direct and indirect factors with a special focus on the effect of salesperson creativity on sales performance. The main components and types of employee competitiveness are elucidated; varieties of factors that influence it are analyzed. The basic tools of employee competitiveness and the special features of its evaluation are investigated. Practical meaning. The practical significance of the obtained results is to develop practical recommendations that would improve competitiveness of the personnel and in conclusion increase the level of company's sales. Prospects for further research. It developes a mechanism of use managerial tools to foster creativity and self-efficacy among personnel for boosting company's sales.

Keywords: personnel competitiveness, management of competitiveness, labor potential, sales, assessment.

\footnotetext{
${ }^{1}$ Pavlo Tychyna Uman State Pedagogical University; Associate Professor at the Department of Marketing, Management and Business Management; ORCID ID: https://orcid.org/0000-0003-0427-3279; e-mail:innakorol88@gmail.com.

${ }^{2}$ Pavlo Tychyna Uman State Pedagogical University; Lecturer at the Department of Marketing, Management and Business Management; ORCID ID: https://orcid.org/0000-0002-2589-3269; e-mail: garmatiuk85@gmail.com.
} 
УДК 338.242.2

\title{
Конкурентоспроможність персоналу та її вплив на продажі компанії
}

\author{
I. В. Король ${ }^{1}$, к. е. н., доцент
}

\section{О. В. Гарматюк ${ }^{2}$}

Стаття надіŭшла: 12.09 .2018

Стаття прийнята: 26.09.2018

Korol I. V., Garmatiuk O. V. Personnel competitiveness and its impact on sales of the company. Економічні горизонти. 2018. № 3(6). C. 26-34. DOI: 10.31499/2616-5236.3(6).2018.156313.

Анотація. Мета дослідження. Головна мета статті полягає в узагальненні теоретикометодологічних принципів та розробці рекомендацій, направлених на покращення управління конкурентоспроможністю персоналу як напряму підвищення рівня продаж компанії. Методологія. Методологія дослідження базується на методах наукового абстрагування, системно-функціонального підходу, групування, узагальнення та формалізації, аналізу й синтезу. Результати. У статті розглядається вплив кадрових факторів на показники продаж компанії. Авторами обгрунтовано, що конкурентоспроможність працівників є не тільки одним з ключових факторів впливу на ріст продаж товарів і послуг, але й на конкурентоспроможність підприємства в цілому. Досліджено основні теоретичні засади конкурентоспроможності працівників. Установлено, що конкурентоспроможність працівника є сукупністю знань, умінь, навичок і особистих якостей, які дозволяють працівникам виконувати свої обов'язки в компанії. Запропоновано модель, що включає прямі та непрямі фактори з особливим акцентом на вплив креативності продавця на ефективність продажів. Виокремлено основні компоненти і типи конкурентоспроможності працівників; проаналізовано різні фактори впливу. Досліджено основні інструменти конкурентоспроможності працівників та особливості її оцінки. Практичне значення. Практична значимість одержаних результатів полягає в розробці практичних рекомендацій, що забезпечать посилення конкурентоспроможності персоналу i, в кінцевому рахунку - підвищення рівня продажів компанії. Перспективи подальших досліджень. Розроблений механізм використання управлінських інструментів для розвитку креативності та самоефективності серед персоналу для стимулювання продажів компанії буде покладено в основу подальших досліджень авторів.

Ключові слова: конкурентоспроможність персоналу, управління конкурентоспроможністю, трудовий потенціал, продажі, оцінка.

\section{Introduction.}

Under condition of competition intensification between economic subjects at all levels, the employee competitiveness serves as the best form of social protection of workers at the plant and in the labor market. This effect is achieved through the implementation of economic (a permanent job, a good job, high variability of wages) and social (a choice of work, self-confidence and confidence in the future) benefits that underlie this complex and multifaceted phenomenon.

Competitive employee due to high quality of work and his ability to implement his competitive advantages meets not only his needs but also the needs of the relevant company. As a result, competitive products that are in demand both domestically and abroad enter the market.

These businesses provide stable sales and high incomes, the saturation of the market with

\footnotetext{
1 Уманський держсавний педагогічний університет імені Павла Тичини; доцент кафедри маркетингу, менеджменту та управління бізнесом; ідентифікатор ORCID: https://orcid.org/0000-0003-0427-3279; e-mail:innakorol88@gmail.com.

${ }^{2}$ Уманський державний педагогічний університет імені Павла Тичини; викладач кафедри маркетингу, менеджменту та управління бізнесом; ідентифікатор ORCID: https://orcid.org/0000-0002-2589-3269; e-mail:garmatiuk85@gmail.com.
} 
competitive goods, worthy compete with foreign producers.

That's why identification main factors that influence personnel competiveness would increase the level of sales of the company and improve its position on the market.

\section{Literature review.}

Problems of personnel competitiveness were researched in the scientific works of domestic and foreign economists such as T. V. Buchynska (Buchynska, 2016), A. G. Shatokhin (Shatokhin, 2000) S. V. Kravtsevych (Kravtsevych, 2005), S. I. Sotnikova (Sotnikova, 2006), O. A. Brusenceva (Brusenceva, 2017), O. A. Grishnova (Grishnova, 2005), T. V. Bilorus (Bilorus, 2018), V. N. Lazarev (Lazarev, 2010), Wang, Guangping (Guangping, 2000) and others.

Nevertheless, the problem of identification main tools that influences personnel competitiveness and in conclusion increases sales of the company is not well represented in the scientific literature.

\section{Research objectives.}

The objective of the article is to analyze personnel competitiveness and its impact on sales of the company.

\section{Results and discussions.}

In modern developing conditions the development of the competitiveness of an enterprise is largely affected by employee competitiveness. Nevertheless, new technology implementation in a company and positive influence of surrounding factors on the performance of an organization, cannot be compared with an impact of highly qualified personnel, which is ready for changes, otherwise the company cannot achieve the desired results (Korol, 2018, p. 74). In economic literature there is no single definition of the term of the personnel competitiveness.

A. G. Shatokhin (Shatokhin, 2000, p. 2) defines the term of the personnel competitiveness as the relation between utility of worker labour qualities in the labour market and a potential buyer, namely an employer.

T. V. Buchynska (Buchynska, 2016, p. 75) defines the personnel competitiveness as a real and potential ability, professional and business competence with great sense of responsibility, which makes significant differences between workers and allows them to be competitive on the market.

S. V. Kravtsevych describes the personnel competitiveness as a comparative characteristics of a worker, which determines the effectiveness of present worker's potential which is implemented through his labour behaviour (Kravtsevych, 2005, p. 155).

S. I. Sotnikova (Sotnikova, 2006, p. 96) defines the personnel competitiveness as a staff ability to individual achievements in labour, contributing to the achievements of organizations.

According to O. A. Brusenceva (Brusenceva, 2017, p. 10) competitiveness of the staff is the ability to realize the complex of natural, professional, social and moral aspects for satisfying market needs in quality goods and services that influence effectiveness of enterprise.

According to O. A. Grishnova (Grishnova, 2005, p. 4), competitiveness of an employee is an accordance of labour market needs, the ability to win on the competitive job market, with better performance than other candidates, meeting of the requirements to employers in terms of their knowledge, skills and personal traits.

V. N. Lazarev (Lazarev, 2010, p. 15) defines the personnel competitiveness as a complex of personal and professional characteristics of the personnel that is able to perceive and analyse the situation quickly, make the best decisions, enabling them to fulfil their responsibilities, and implement in the labour market effectively.

In our opinion, employee competitiveness is a combination of knowledge, abilities, skills and personal traits that enable employees to fulfil their responsibilities in a company and be demanded on labour market.

The studying of the personnel competitiveness as an integrated characteristic and complex systems involves the need to study and analyse some components of labour 
potential, among which there are: physiological, vocational and qualification, and status components.

Thus, physiological component of labour potential is defined according to psycho-physiological characteristics of personnel and it includes the elements such as gender, age, health status, personal staff qualities (activity, creativity, initiative, motivation type, needs, etc.).

Vocational and qualification component of labour potential is determined by such vocational and qualification characteristics of personnel as its degree of education and qualifications, work experience in the profession, professional mobility.

Status component of labour potential is determined by social status and the assessment of the prestige of the profession by the employee, his family, colleagues and friends.

Each of these elements of work potential of a particular individual may create either competitive labour advantage, or vice versa it may obstruct him on competitive job market. Therefore, we consider it reasonable to study the features of the competitive advantages of employees as the basis of their competitiveness. Thus, in the economic literature there are following types of competitive advantages: inherited and acquired.

Inherited competitive advantages include the aptitudes (cleverness, talent, genius, ability for this type of activity), temperament, and physique.

Acquired competitive advantages include: business skills (education, specialist knowledge, skills and abilities); intelligence and culture; purposefulness of the work motivation (ability to set personal goals and team goals); character (attitude to work, to others, to oneself, to things); emotionality (ability to control one's emotions, will, stress resistance, etc.); sociability, communication skills, organized character; age and so on.

The classification of the personnel competitiveness into inherited and acquired ones is conventional. For example, the ability to a particular type of work is accumulated as the ex- perience gained in this branch. But other aspects of the abilities - cleverness, genius, talent are mostly determined by inherited. Physique is mainly people's hereditary factor that can be improved by means of individual training or in other ways.

Competitive advantages of employees, depending on the availability of documentary evidence are: subjective (personal qualities, professional mobility, prestige estimation) and objective (gender, age, health, education, qualifications and work experience).

Based on theories of creativity and the theoretical and empirical evidence available in the sales literature, we consider a model of sales performance incorporating the construct of salesperson creativity as an important and direct antecedent to performance (Guangping, 2000, p. 4).

The model is illustrated in Fig. 1. This model proposes three direct factors that influences sales performance: work effort, creativity, and selling experience.

In our opinion, another factor that influences directly sales performance is motivation. To optimize sales company needs to have a highly-motivated team. Motivation focuses on seller attitudes, leadership's ability to create and sustain selling energy. Nowadays, foreign companies focus on special meetings, conferences, training programs to support corporate standards and corporate culture with orientation on selling (Garmatiuk, 2018, p. 54-55).

This is in line with the long tradition of viewing sales performance as a function of motivation and skills and the more recent research that emphasizes both working hard and working smart for effective selling.

The salesperson's selling experience has been posited as another important predictor of job performance. Experience leads to higher levels of sales-related knowledge and skills and has been found to influence a number of important variables such as motivation, job skills, role perceptions, customer orientation, and finally, performance. 


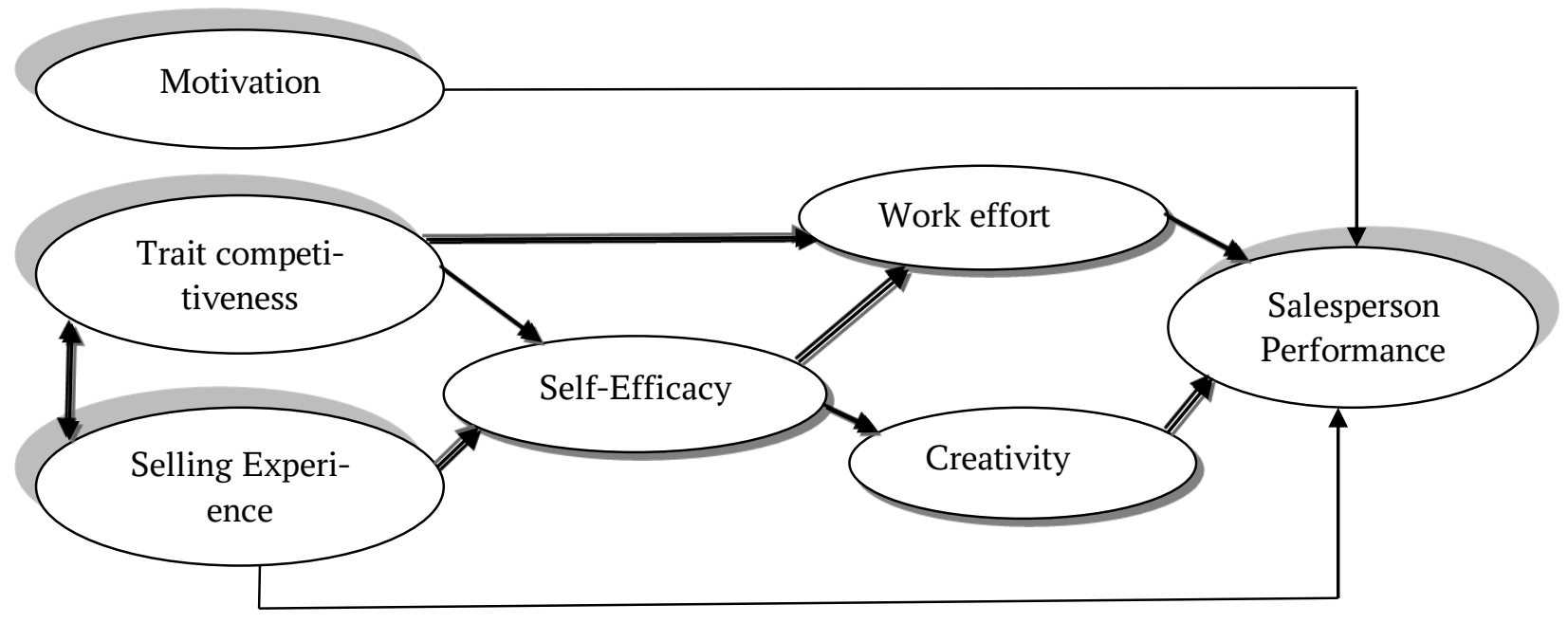

Fig. 1. Model of salesperson performance

Source: Is improved by the authors.

This is in line with the long tradition of viewing sales performance as a function of motivation and skills and the more recent research that emphasizes both working hard and working smart for effective selling.

The salesperson's selling experience has been posited as another important predictor of job performance. Experience leads to higher levels of sales-related knowledge and skills and has been found to influence a number of important variables such as motivation, job skills, role perceptions, customer orientation, and finally, performance.

Experienced salespeople have been suggested to have a better understanding of their jobs, customers, and company policies.

The final direct determinant of sales performance in the model is the salesperson's creativity. Salesperson creativity is conceptualized as different from scientific and artistic creativity in that the former represents smaller deviations from daily routines while the latter tends to be greater in scope and degree. In this regard, salesperson creativity is posited as being primarily affected by the individual's selfefficacy beliefs.

Indirect factors of sales performance as well recognized in the sales literature, personal characteristics play a significant role in determining the salesperson's performance. The proposed model posits three indirect antecedents of sales performance: self-efficacy, trait competitiveness, and selling experience.

Self-efficacy, a central construct in social cognitive theory, refers to people's judgments about their capability to organize and execute courses of action required to attain particular designated types of performance. It has been suggested that the effect of self-efficacy on task performance is primarily through enlistment of effort and creative use of capabilities and resources. Research has shown that employees who feel efficacious of performing particular tasks will persist at them in the face of adversity and cope more effectively with change.

The proposed model incorporates two exogenous constructs, selling experience and trait competitiveness, as predictors of self-efficacy. These two constructs have been consistently regarded as extremely important determinants of sales performance, and their role as individual level determinants of the salesperson's self-efficacy cannot be overestimated. Social cognitive theory posits that self-efficacy beliefs can be enhanced in a number of ways, the most effective of which is mastery experiences.

Selling experience provides the knowledge and skills that salesperson can rely on to effectively deal with different sales problems, thus increasing the level of self-efficacy. 
Trait competitiveness is the enjoyment of interpersonal competition and the desire to win and be better than others. The mechanism by which this trait affects performance is not clear enough, however. It is suggested here that competitiveness is likely to affect performance indirectly through its effects on work effort and self-efficacy.

In the article "Drivers of sales performance: a contemporary meta-analysis. Have salespeople become knowledge brokers?" Verbeke, Dietz and Verwaal (2011) identified 18 main measurable characteristics that can determine Sales Performance of a Salesperson. Of these 18, their empirical study of narrowed it down to 5 main traits: These where Selling Related Knowledge, Degree of Adaptiveness, Role Ambiguity, Cognitive Aptitude and Work Engagement.

None of these factors stands alone, and each in turn influences the other and is influenced by both external and internal factors. As Verbeke et. al. (2011) found, the process of selling has developed a long way from product sales to service sales and is now entering a phase of knowledge based selling.

This means that traits and abilities of sales people become more and more important and can directly influence company profitability. To be able to measure these traits and take into consideration the effect they have in developing both sales and HR strategy, it is important to understand the effect in the sphere of sales performance, and why they affect results the way they do. In their analysis, identified a variety of different types of measurement and outside factors that influence sales performance, which they refer to as Moderators (Verbeke, 2011, p. 410).

T. V. Bilorus (Bilorus, 2018, p. 187) consider rating indicators of competitiveness of the personnel management system of the company as the result of the interaction of such factors: motivation system; the management of the system of recruiting, adaptation and staff assessment; the level of organization and development of social infrastructure of the company; the state of socially-psychological climate; corporate culture and image of enterprise; professional training and system of development of staff; system of planning and marketing of personnel.

The formation and development of the personnel competitiveness is affected by the factors which are divided into two groups according to their source of impact: internal (factors that impact due to the personnel and organization) and external (factors of micro-and macro environment of the organization) (Egorshin, 2007, p. 654).

The factors affecting the competitiveness of the personnel are also the determinants of the employment potential components (psycho-physiological, professional qualification, status). The effect of the organization on competitiveness is determined by created organizational, social and psychological conditions that form and contribute to the development of employee competitiveness (Grishnova, 2005, $p .4)$. These include such groups of factors as work team, salary, workplace, company management, professional career, social security and social welfare.

External factors of the personnel competitiveness are a complex of acting individuals and forces outside the organization that affect the maintenance and development of the personnel competitiveness. These include: mediators, suppliers, competitors, consumers, demographics, economics, environment, technology, politics, culture, etc. (Meskon, Albert and Hedouri, 2005, p. 455). Basic components of the employee competitiveness are presented in Fig. 2.

The concept of employee competitiveness can be classified according to various criteria, thereby determining its basic types.

1. Depending on the achieved level there is the personnel competitiveness of high, medium and low level.

The high level of the competitiveness provides a combination of competitive advantages of personnel on the basis of its characteristics (professional qualification, physiological, motivational, corporate, etc.) that fully meet the requirements of production. 


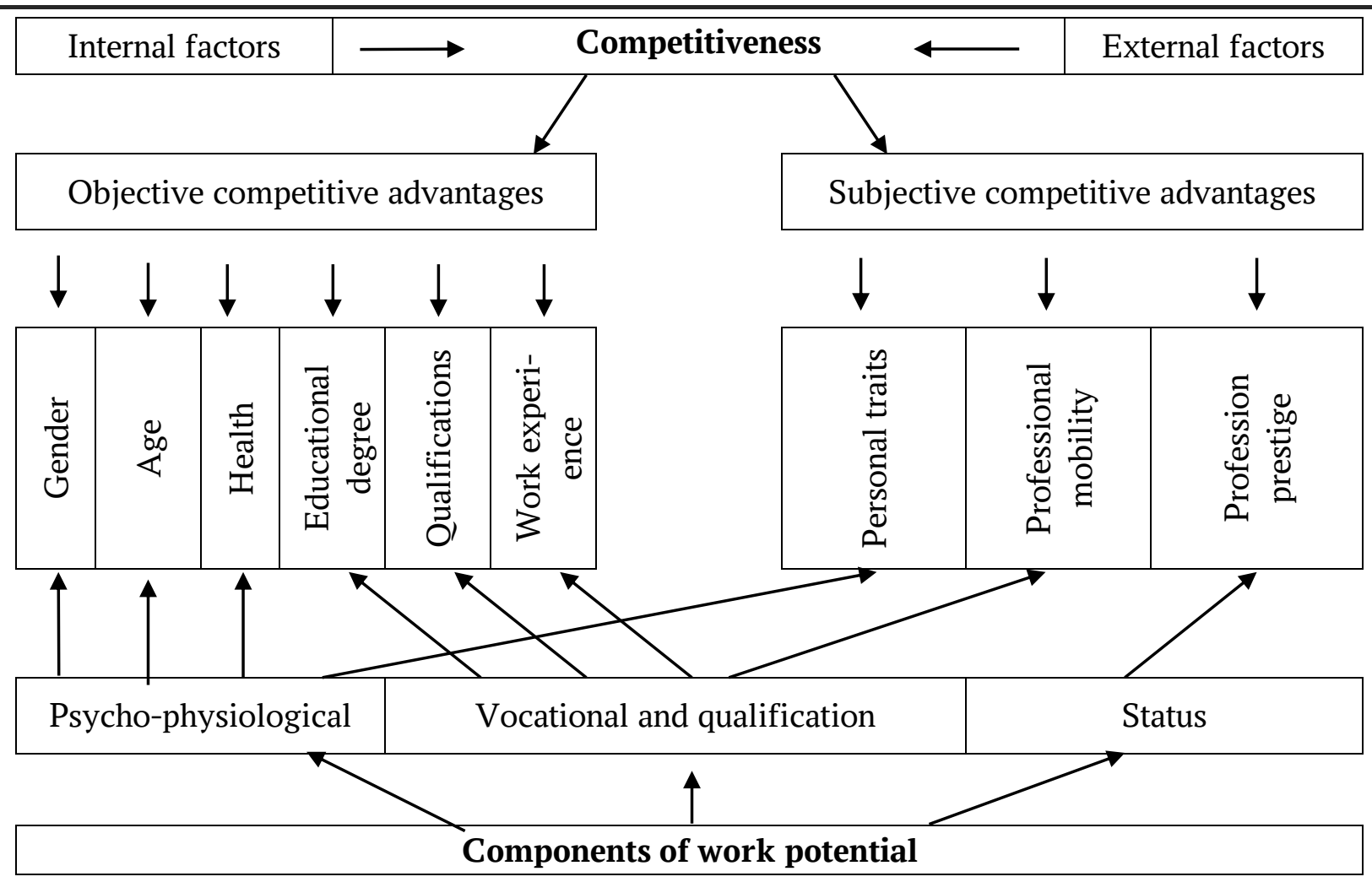

Fig. 2. The key elements and factors of the personnel competitiveness

Source: prepared by the authors.

The average level of the competitiveness is typical to the personnel imparted partial matching of the characteristics of the labour potential (all or several) to the proposed requirements and according to the evaluation results these workers are less confident in the stability of their employment both within the enterprise and beyond it. The low level of the competitiveness is peculiar to the employees having unacceptably low estimation rate on one or several characteristics in comparison with the required ones.

2. Depending on the number of evaluated characteristics there can be distinguished an element-based (it is defined by any one of the characteristics of the work potential (e.g., work experience)) and general competitiveness (it provides a comprehensive analysis of the development of employee work potential) (Sotnikova, 2006, p. 100).

3. Depending on the tested individual there can be distinguished: individual (it describes the level the development of the characteristics of labour potential of a particular employee) and group or competitiveness of groups (it studies the competitiveness of certain age and gender workers, professional and qualification or other groups of different categories of personnel, and of the whole enterprise).

4. Depending on the site of labour application there are internal (the competitiveness of the personnel within the enterprise) and external competitiveness (the competitiveness outside the enterprise).

5. Depending on the type of prevailing competitive advantages there are absolute and relative competitiveness. The absolute competitiveness allows the personnel to reproduce itself continually, to rise professionally, and improve itself. Such personnel respond to social and economic changes with flexibly that allows it to maintain its competitiveness at a sufficient level. Relative competitiveness is connected with the fact that to a greater degree its level is less supported by the staff itself, but by external conditions, such as relations, acquaintances, etc., which are usually of a temporary nature. At any time, regardless of employees the characteristics can shift from a 
competitive advantage to a factor of non-compliance with presented requirements.

6. Depending on the causes influencing the dynamics of competitiveness there can be distinguished: factor, structural and situational competitiveness.

The competitiveness factor is associated with changes within the personnel, namely its level of certain characteristics of the work potential. Thus, the external conditions related to the personnel may remain unchanged, or they may be evolutionary in nature, that is associated with ongoing, daily changes (industrial, economic, social and other) in the life of the enterprise. Structural competitiveness is associated with a sharp change in personnel in terms of compliance of its certain characteristics of the work potential to the required regulations because of some independent on its (personnel) reasons.

Situational competitiveness is associated with regional (including natural, climatic, geographic) characteristics of the production, but also it is determined by the status of a particular company in the region (Shatokhin, 2000, $p$. 3).

As companies have different levels of technological and technical development, unequal financial status, level of management, corporate culture and requirements are different for employers to set competitive skills of employees and a reasonable valuation of labour services workforce. Of course, the last affects the equilibrium price of such services on the labour market, especially in a particular area or a particular segment of the labour market, as well as general trends such as the increasing demand for the ability to work with information, professional mobility, adaptability and so on.

It is important to emphasize that attempts to assess the competitiveness of the staff always include a conformity assessment of certain components of the labour potential indicators of competitiveness.

We consider some methodological approaches to the assessment of the competitiveness of workers. Thus, evaluating the competitiveness of a particular category of staff according to R. A. Fatkhutdinov is recommended as follows:

$$
K_{n}=\sum_{i=1}^{n} \sum_{j=1}^{7} \frac{a_{i} \cdot b_{i j}}{5 \cdot n}
$$

where $K_{n}$ - the competitiveness of specific categories of staff, $n$ - number of experts, 7 - quantity of quality of staff to be considered, $a_{i}$ - importance of quality, $b_{i j}$ - experts' estimation of personnel competence according to five-point scale: 1 - no quality, 2 - appears quite rarely, 3 - not very evident and mild, 4 appears often, 5 - appears systematically (Shatokhin, 2000, p. 2).

Comprehensive assessment of the competitiveness of $K_{i j}$, proposed by I. L. Petrova, is built using the points $a_{i j}$ and $b_{i j}$ of significance criteria used for it:

$$
K_{i j}=\stackrel{\circ}{a} a_{i j} \times b_{i j} .
$$

Methodological approaches developed by O. Grishnova and O. Shpyrko are based on the fact that competitiveness is a function of the personnel of its quality and price (Shatokhin, 2000, p. 2), and the method provides for application method and magnitude involving weights to determine the validity of certain indicators of competitiveness.

Designated methodological approaches O. A. Grishnova, I. L Petrova and other scientists have significant advantages, allowing the selection of the most competitive workers in the labour market positively be put on improving the quality of the labour potential of individual employees and the company as a whole.

\section{Conclusions.}

In modern developing conditions the working out and the introduction of the personnel competitiveness management system by each enterprise is regarded as one of its main competitive advantage which enhances the its sales of goods or services and total competitiveness of the enterprise. 
In this context, the effective personnel competitiveness management is one of the most important tasks of modern enterprise management.

\section{References}

Arapova, O. M. (2015), “Competitiveness of personnel and value of enterprise”, Efektyvna Ekonomika, [Online], no. 7, available at: http://www.economy.nayka.com.ua/index.php?op=1\&z=4203 (Accessed 8 September 2018).

Brusientseva, O. A. (2017), "Competitiveness of the personnel as a component of the competitiveness of the enterprise" Naukovyi visnyk UMO. Seriia. Ekonomika ta upravlinnia, vol. 3. available at: http://umo.edu.ua/images/content/institutes/imp/vydannya/visnyk umo/ekonomika/V 3/Брусенцева.pdf (Accessed 8 September 2018).

Buchynska, T. V. (2016), "Competitiveness of the personnel as the main factor in improving the efficiency of the enterprise”, Naukovyi visnyk Uzhhorodskoho natsionalnoho universytetu, no. 10 (1), pp. 74-77.

Egorshin, A. P. (2007), Upravlenie personalom: uchebnik dlja vuzov [Human Resource Management: a textbook for universities], NIMB, Novgorod, Rosija.

Fathutdinov, R. A. (2002), Konkurentosposobnost' organizacii v uslovijah krizisa: jekonomika, marketing, menedzhment [Competitiveness of an organization in a crisis: economy, marketing, management], Marketing, Moscow, Russia, 885 p.

Garmatiuk, O. V. (2018), "Modern system of sales of enterprises”, Intelekt XXI, vol. 3, pp. 52-55.

Hlopova, T. V. (2004), "Development of labor potential and increasing the competitiveness of enterprise personnel”, Ph.D. thesis, Economy and National Economy Management, Baikal State University of Economics and Law, Irkutsk, Russia.

Hrishnova, O. A. (2005), “Competitiveness of the personnel of the enterprise” Ukraina: aspekty pratsi, vol. 3, pp. 3-9.

Hrishnova, O. and Shpyrko, O. (2004), "Competitiveness of the personnel of the enterprise: criteria of determination and indicators of measurement" Ukraina: aspekty pratsi, vol. 3, pp. 3-9.

Kravtsevich, S. V. (2005), "Developing methodological assessments of the competitiveness of workers in the labor market", Ph.D. thesis, Economy and National Economy Management, Baikal State University of Economics and Law, Irkutsk, Russia.

Lazarev, V. N. (2010), Upravlenie konkurentosposobnost'ju personala vysshego uchebnogo zavedenija [Managing the competitiveness of higher education personnel], UlGTU, Ulyanovsk, Russia, $204 \mathrm{p}$.

Meskon, M., Albert, M. and Khedouri F. (1997), Osnovy menedzhmenta [Fundamentals of management], Delo, Moscow, Russia, 720 p.

Petrova, I. L.(1997), Sehmentatsiia rynku pratsi: teoriia i praktyka rehuliuvannia [Segmentation of the labor market: the theory and practice of regulation], In-t ekonomiky, upravlinnia ta hospodarskoho prava, Kyiv, Ukraine, $298 \mathrm{p}$.

Shatohin, A.G.(2000), "Competitiveness of workers in the labor market”, Ph.D. thesis, Political Economy, Yaroslavl State University named after P. G. Demidov, Yaroslavl, Russia.

Sotnikova, S. I. (2006), “Competitiveness in the labor market: the genesis of socio-economic content”. Marketing in Russia and abroad - Marketing $v$ Rossii i zarubezhom, no. 2, pp. 95-107.

Verbeke, W., Dietz, B., and Verwaal, E. (2010), “Drivers of sales performance: a contemporary meta-analysis. Have salespeople become knowledge brokers?", Journal of the Academy of Marketing Science, vol. 39, no. 3, pp. 407-428, doi: https://doi.org/10.1007/s11747-010-0211-8.

Wang, G. (2000), "Personal factors affecting sales performance: modeling the effects of experience, competitiveness, self-efficacy, effort, and creativity", LSU Historical Dissertations and Theses, 147 p., available at: https://digitalcommons.lsu.edu/gradschool_disstheses/7236/ (Accessed 8 September 2018).

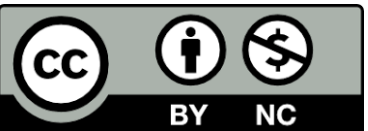

Цей твір ліцензовано на умовах Ліцензії Creative Commons «/з Зазначенням Авторства - Некомериійна 4.0 Міжнародна» (CC BY-NC 4.0). This is an open access journal and all published articles are licensed under a Creative Commons "Attribution-NonCommercial 4.0 International" (CC BY-NC 4.0). 